\title{
Self-medication with antibiotics of parents of different nationalities in China: analysis of irrational use of antibiotics from demand side
}

\section{Zhongliang Zhou}

Xi'an Jiaotong University

\section{Dantong Zhao}

Xi'an Jiaotong University

\section{Huarui Zhang}

Xi'an Lianhu District Huoshaobei Clinic

\section{Chi Shen}

Xi'an Jiaotong University

\section{Liang Zhu ( $\sim$ liangjulia0317@163.com )}

Associate professor of Air Force Medical University in Xi'an Shaanxi Province,China. My research interests include health economics analysis and health policy research.

\section{Yaxin Zhao}

Xi'an Jiaotong University

\section{Dan Cao}

Xi'an Jiaotong University

\section{Yangling Ren}

Xi'an Jiaotong University

\section{Yafei Si}

Yale University

\section{Siwei Ma}

Xi'an Jiaotong University

\section{Yu Fang}

Xi'an Jiaotong University

\section{Research article}

Keywords: China; Self-medication with antibiotics; Parents of different nationalities; Knowledge; Attitudes; Behaviors

Posted Date: October 15th, 2019

DOI: https://doi.org/10.21203/rs.2.16085/v1 
License: (c) (i) This work is licensed under a Creative Commons Attribution 4.0 International License. Read Full License 


\section{Abstract}

Background: There is an increasing trend on practicing self-medication with antibiotics in both developed and developing countries. Bacterial resistance caused by antibiotic use has become an important public health concern. This study contributes to explore the effect of different demanders but the same supplier on parental self-medication with antibiotics for children. It intends to analyze the difference in selfmedication with antibiotics of parents of different nationalities for children under the same health service supplier in the context of Chinese policies, and compare their differences in knowledge, attitudes and behaviors about antibiotics. Methods: A cross sectional study was designed to investigate all 310 parents of different nationalities (Chinese, other Asian and Occidental) whose children were studying in an International Department of an International School in Xi'an, Shaanxi, China on September 2018. Pearson Chi-square test and Binary Logistic Regressions were used to analyze the data. Results: The results showed the rate of parental self-medication with antibiotics for children was $13.85 \%$, where parents of three nationalities were respectively $20.10 \%, 5.00 \%$ and $2.67 \%(P<0.001)$. Chinese parents were respectively $8.221(P<0.01)$ and $6.086(P<0.05)$ times more likely to have self-medication with antibiotics for children compared to Occidental parents in two regression models controlling different confounders. Occidental parents had higher correct rate of knowledge, attitudes and behaviors about antibiotics than Chinese parents and followed by other Asian parents in total $(P<0.001)$. Conclusions: The study found that parents' nationality was an influencing factor on parental selfmedication with antibiotics for children that Chinese parents were easier to self-medicate for children than Occidental parents. Occidental parents performed better than Chinese and other Asian parents in knowledge, attitudes and behaviors about antibiotics. It is recommended for health administration not only to strengthen the supervision and regulation to health service supplier, but also health education to parents on knowledge, attitudes and behaviors about antibiotics. Key words: China; Self-medication with antibiotics; Parents of different nationalities; Knowledge; Attitudes; Behaviors

\section{Background}

Antibiotics are commonly used as drugs to treat disease caused by bacterial infections. As an inevitable main side effect of antibiotic use, bacterial resistance has become an important public health concern that threatens the residents' health[1]. Both appropriate and inappropriate antibiotic use can drive antimicrobial resistance[2]. Irrational and excessive use of antibiotics, even abuse, not only increase disease morbidity and mortality, reduce the efficiency of disease treatment, increase the economic burden of patients and society, but also make it easy to cause the emergence of drug-resistance bacteria or multidrug-resistance bacteria, which does more enormous and serious harm to human health[3]. The World Health Organization have reported that respiratory diseases, infectious diarrhea, measles, AIDS and tuberculosis account for more than $85 \%$ of global deaths caused by infection, and whose causes are almost $100 \%$ related to bacterial resistance[4]. As the World Health Organization pointed out that "a postantibiotic era-in which common infections and minor injuries can kill everything-far from being an apocalyptic fantasy, is instead a very real possibility for the 21 st century"[5]. 
China is the world's largest producer and user of antibiotics, whose annual output of raw materials of antibiotics are about 210,000 tons and the annual per capita consumption is about $138 \mathrm{~g}$, up to 10 times higher than that in America[6]. In China, antibiotic abuse is serious and the growth rate of which is also faster than other countries in the world[6]. Previous studies have shown that the irrational and excessive use of antibiotics are caused by a combination of factors such as supply side and demand side. The supply side factors mainly included improper supervision by the health sector[7], corruption in the health sector[8, 9], profit-seeking behavior in doctor's prescription[10] and the lack of knowledge and attitudes about antibiotics of doctors[11] and so on. The demand side reasons were the self-medication with antibiotics caused by the lack of knowledge, attitudes and behaviors about antibiotics of the populationtailored[12-14], mainly including teachers[15], students[16], parents of children and adolescents[17, 18] as well as residents[19, 20] in hospital[21], community[22] and school in the same country or region. However, what the existing studies have reflected on antibiotic overuse is a combination influence on health service supplier and the demander in the same country or region, instead of comparing the effect of different demanders under the same health service supplier on antibiotic overuse. For a instance, both Occident and China have antibiotic abuse problems, and China's per capita annual consumption is about 10 times than that in America[6]. However, what accounts for this difference is the result of the mixture effect of both the health service supplier (China or America) and the demander (residents), it is impossible to distinguish the demander factor's contribution to this difference from combination effect of supplier and demander by previous findings.

There is an increasing trend on practicing self-medication with antibiotics in both developed and developing countries recently, which is regarded as the common phenomenon of irrational antibiotic use and the cause of bacterial resistance[23,24]. Self-medication can be defined as the use of drugs to treat self-diagnosed disorders or symptoms, or the intermittent or continued use of a prescribed drug for chronic or recurrent disease and symptoms. In practice, it also includes medication for family members, especially the therapy for children or the old on one's own [25]. This behavior is normally done by the consumer rather than prescriber. Previous studies have presented that children and adolescents are the most widely users on antibiotics[26], whose medicines are usually purchased by parents themselves[27], naturally resulting in parental self-medication with antibiotics and making antibiotic abuse much more common[28]. As far as the children and adolescents' body functions are at the developmental stage, there is no doubt that the irrational use of antibiotics indeed has a certain adverse impact on their growth, development and metabolism.

Many studies have illuminated that the main reasons for parental self-medication with antibiotics for their children were that they thought they have enough past experience to medicate children[29], ailment with no need to see doctors[30], unclear knowledge of indications for antibiotics[31]. However, the previous studies most only aimed at parental self-medication with antibiotics for their children in local area or country with the same demanders under the same supplier, instead of thoroughly comparing the difference of self-medication with antibiotics for children of parents of different nationalities in a country or region, which represents the different demanders under the same supplier condition. Since the use of antibiotics is determined by the combination factors of health service supplier and demander, and 
existing studies couldn't be able to specifically separate the demander contribution from combined effect on antibiotic use, which make it less conducive to put up with targeted policy recommendations from the perspective of the demand side. This study is intended to explore the difference in self-medication with antibiotics of parents of different nationalities for their children under the same health service supplier with unified health environment and health norms in the context of Chinese policies, and compare their differences in knowledge, attitudes and behaviors about antibiotics, as well as analyze the effect of parents' nationality on parental self-medication with antibiotics for children. What's more, this study has a great practical significance to formulate relevant health policies and reduce the overuse of antibiotics from the perspective of the demand side.

\section{Methods}

\section{Study design}

Different from the previous study designed by analyzing self-medication with antibiotics of the same demanders under the same supplier, this study aims to explore the difference in self-medication with antibiotics of parents of different nationalities for their children under the same health service supplier with unified health environment, health norms and doctors' behaviors on behalf of different demanders and the same supplier, reveal the effect of parents' nationality on parental self-medication with antibiotics for their children under the control of health service supplier, as well as compare their differences in knowledge, attitudes and behaviors about antibiotics.

\section{Data resource and collection}

A cross sectional study investigated all parents of different nationalities (Chinese, other Asian and Occidental) whose children are studying in kindergartens, elementary schools, junior high schools and high schools in an International Department of an International School in Xi'an, Shaanxi Province, China on September 2018. The anonymous investigation was explained and completed between the respondents and trained investigators face to face, and the questionnaires were collected on the spot in order to ensure the quality of the survey. Of the 310 questionnaires that were distributed, 296 were returned completely. The response rate was $95.48 \%$.

\section{Data instrument and management}

The questionnaire consisted of two parts. The first part was the socio-demographic characteristics of the respondents and whether there was parental self-medication with antibiotics. The second part was the three blocks of knowledge, attitudes and behaviors about antibiotics. Table 1 showed the description of questionnaire. 50 volunteers were pre-investigated in order to ensure the validity and length of the questionnaire. (Insert Table 1 here) 


\section{Statistical analysis}

The data was entered into a database using the Epidata 3.1, and transferred to PASW statistical software (IBM Corporation, Armonk, NY, USA, version 18.0) for all analysis. Descriptive analysis was used to describe the socio-demographic characteristics and knowledge, attitudes and behaviors about antibiotics of the respondents. Pearson Chi-square test was used to evaluate whether self-medication with antibiotics of parents of different nationalities for children in the past six months had a difference, so did knowledge, attitudes and behaviors about antibiotics. What's more, two binary logistic regressions models were used to analyze the effect of different nationalities on parental self-medication with antibiotics, with the dependent variable of having self-medication with antibiotics or not. In terms of Model 1, the confounders of socio-demographic characteristics of the respondents were controlled. The confounders of both socio-demographic characteristics and knowledge, attitudes and behaviors about antibiotics of the respondents were controlled in Model 2. $P$ value was at the significance level $a=0.05$.

\section{Results}

\section{General socio-demographic characteristics of the respondents}

As shown in Table 1, out of all respondents, 121 were Chinese parents (40.88\%), 100 were other Asian parents $(33.78 \%)$ and 75 were Occidental parents $(25.34 \%)$. The proportion of female was respectively $84.30 \%, 73.00 \%$ and $37.33 \%$ among three nationalities, and the average mean age of the respondents were $37.96,40.76$ and 39.44 .

\section{Self-medication with antibiotics of parents of different nationalities}

We found that there were $13.85 \%$ of the respondents reported that they had self-medicated with antibiotics for children in the past 6 months. Chinese parents' rate of self-medication with antibiotics was $20.10 \%$, while other Asian parents and Occidental parents were respectively $5.00 \%$ and $2.67 \%(P<0.001)$. The rate of self-medication with antibiotics of Chinese parents was higher than that of other Asian parents and Occidental parents.

\section{Logistic regression analysis on parental self-medication with antibiotics}

The result of Model 1 and Model2 of Logistic regression analysis examining the influencing factors of parental self-medication with antibiotics is conducted and presented in Table 3, where the confounders of socio-demographic characteristics of the responders and both socio-demographic characteristics and knowledge, attitudes and behaviors about antibiotics of the responders were controlled respectively in 
two models . Nationality of parents was regarded as the explanatory variable, and whether having selfmedication with antibiotics for children in the past 6 months was the explained variable. We identified that parents' nationality was the influencing factor of parental self-medication with antibiotics for their children, Chinese parents were 8.221 times in Model $1(P<0.01)$ and 6.086 times $(P<0.05)$ in Model 2 more likely to have self-medication with antibiotics compared to Occidental parents. In addition, the rate of selfmedication with antibiotics of parents aged 25-34 was 6.130 times than that of parents aged 40-55 $(P<0.01)$, parents considering that antibiotics should be purchased by a prescription were 0.011 times than those who didn't think so about self-medication with antibiotics $(P<0.01)$, and parents who asked for a doctor to prescribe antibiotics were 15.288 times as much compared to those who didn't have such behavior $(P<0.01)$.

\section{Knowledge, attitudes and behaviors about antibiotics of parents of different nationalities}

We explored the difference in knowledge, attitudes and behaviors about antibiotics of parents of different nationalities. Knowledge about antibiotics results are presented in Table 4. Totally, the correct knowledge about antibiotics of parents of different nationalities was significantly different $(P<0.001)$. Items such as "Antibiotics aren't anti-inflammatory drugs", "Antibiotics can't kill or inhibit the virus", "Antibiotics are purchased by a prescription", "Repeatedly using an antibiotic is prone to have bacterial resistance" showed that the correct rates of antibiotic knowledge of Occidental parents were higher than those of Chinese parents and followed by other Asian parents $(P<0.05)$. There was a best awareness in the item "Repeatedly using an antibiotic is prone to have bacterial resistance" of parents from three nationalities with $84.30 \%, 76.00 \%$, and $90.67 \%$ respectively.

We found that parents of three nationalities had a significant difference in correct attitudes about antibiotics in total $(P<0.001)$ as Table 5 shows. Items such as "Disagree that antibiotics should be used immediately when your child has Upper Respiratory Tract Infections", "Disagree that expensive antibiotics will work better with fewer side effects", "Disagree that intravenous antibiotics (infusion) are better than oral antibiotics", "Disagree that parents can self-medicate with antibiotics for their children based on their children's condition when disease is mild" showed that Occidental parents' correct rates of antibiotic attitudes were higher than those of Chinese parents and followed by other Asian parents $(P<0.05)$.

In addition, a significant difference in behaviors about antibiotics of parents of three nationalities was identified in Table $6(P<0.001)$ with the result that less such behavior, the better performance. The following items "Antibiotic is available at home to medicate children timely when they are sick", "Will give children multiple antibiotics at the same time when they are sick", "Will use leftover antibiotics if children have similar symptoms", "Will change the dosage of antibiotics according to the course of disease of children", "Will change the type of antibiotics when you use antibiotics" presented that Occidental parents had a better antibiotics behaviors than Chinese parents and followed by other Asian parents $(P<0.001)$. 


\section{Discussion}

Unnecessary and irrational use of antibiotics is a major cause of bacterial resistance[32]. Children and adolescents are the most widely users of antibiotics[28], whose medicines are mostly purchased by their parents[29], which makes parental self-medication with antibiotics much more common and accelerates the bacterial resistance. Parental self-medication with antibiotics for children exists in both developing and developed countries, with high rate in southern and eastern Europe reported repeatedly[33], as well as in Africa[28] and Asia[34]. Different from the previous studies analyzing self-medication with antibiotics designed and compared by the same demanders under the same supplier, this study aims to analyze the difference in self-medication with antibiotics of parents of different nationalities for their children under the same health service supplier in China on behalf of different demanders and the same supplier, reveal the effect of parents' nationality on parental self-medication with antibiotics for their children under the control of health service supplier, as well as compare their differences in knowledge, attitudes and behaviors about antibiotics.

\section{Self-medication with antibiotics of parents of different nationalities for children}

Previous studies have reported that the rate of Chinese parental self-medication with antibiotics for children was $18.0-59.4 \%[35]$, with $25.0 \%$ in urban and $18.0 \%$ in rural, and $59.4 \%$ [14] in Hefei. Occidental parents of which was $4.0-28.0 \%$, such as $4.0 \%$ in urban area and $12.1 \%$ in suburban area in the US[36], $5.0 \%$ in the UK[37], 22.7\% in the Greece[38], 28.0\% in the southern of Spain[39]. As for other Asians, the rate was 39.5-59\%, like 39.5\% in Jordan[40], 57\% in Syria[34], 46\% in United Arab Emirates[41], 43.9\% in Saudi Arabia[42], 40\%-60\% in Vietnam[43] and 59\% in the western of Nepal[44]. In our study, $13.85 \%$ parents self-medicated with antibiotics for children in the past 6 months, while $20.10 \%$ was Chinese, $5.00 \%$ was other Asians and $2.67 \%$ was Occidental parents. The reason that the self-medication with antibiotics rates of other Asian and Occidental parents in our study are lower than the previous studies' findings is probably that China has issued a "Restriction Order" that antibiotics should be purchased by prescriptions[45] as early as 2004 , and that all types of health institutions have been strictly required to implement antibiotics classification management and physician prescription authority management on March 3, 2017, which restricts the antibiotics purchased without prescription in China to some extent and decreases parental self-medication with antibiotics for their children in China effectively. Furthermore, we found that the self-medication with antibiotics rate of Chinese parents was the highest $(20.10 \%)$, and Occidental parents lowest (2.67\%). Although it is the same as the agreement that parental selfmedication with antibiotics rate in China was higher than that in Occident as the studies showed before, our study is truly of great importance to reveal the essential difference of parents of different nationalities by exploring the difference in self-medication with antibiotics of parents of different nationalities on behalf of various demanders but under the same health service supplier, which means more than previous studies isolated to analyze and compare the parental self-medication with antibiotics by the same demanders (parents of the same nationality) under the same supplier (the same country or region). 
The results of our study reflect that Chinese parents are still more likely to self-medicate with antibiotics for their children than Occidental parents although they both are under the same background of health service supplier. What accounts for this may because that residents' antibiotic education is still insufficient in China, far from reaching the level of Occident. The government should make efforts on strengthening the publicity and education of residents' knowledge on antibiotic use and further control the irrational use of antibiotics.

\section{Influencing factors of parental self-medication with antibiotics for children}

We matched two logistic regression to analyze the effect of parents' nationality on self-medicate with antibiotics for their children by controlling the confounders. Model 1 controlled confounders of sociodemographic characteristics of the responders and knowledge, attitudes and behaviors about antibiotics of the responders were also adjusted in model 2. Both two models steadily indicated that the difference in parents' nationality did have an effect on parental self-medication with antibiotics, and that Chinese parents were 8.221 and 6.086 times respectively more likely to have self-medication with antibiotics for their children compared to Occidental parents. It may because of the worse knowledge and attitudes about antibiotics of Chinese parents compared to Occident and their own different traditional concepts. In Chinese society, the growth of children is paid much more attention by parents[27] even indulged. Ailments can cause excessive sensitivity and tension in family, resulting in a common phenomenon that "people at death's door turn in desperation to any doctor". Many studies have identified that parents usually misuse antibiotics when children suffer the Upper Respiratory Tract Infection for symptoms such as fever, cold and cough[46-48], and overuse antibiotics for the reasons of parents' unclear knowledge about antibiotics, medication by past experience[24], thinking symptoms are not severe[49], having leftover antibiotics at home[50] and so on. Compared to Occidental parents' lighter sensitivity and tension, Chinese parents are much easier to practice self-medication with antibiotics for their children. In addition, we also found that parents aged 25-34 had a higher rate of self-medication with antibiotics than parents aged 40-55, same as the related studies [34,51]. Besides, parents considering that antibiotics should be purchased by a prescription were less likely to self-medicate with antibiotics than those don't think so, and parents who asked for doctors to prescribe antibiotics were more prone to practice selfmedication with antibiotics. In order to reduce the rate of parental self-medication with antibiotics, improve the knowledge and attitudes about antibiotics of the masses, and regulate antibiotic use to reduce the bacterial resistance, it is necessary not only for the government to further strengthen the management and supervision of antibiotic purchased by prescription, and improve the doctors' rights of antibiotic classification and prescription, but also for the related departments in society to positively popularized health education on knowledge involved in antibiotics.

\section{Knowledge, attitudes and behaviors about antibiotics of parents of different nationalities}


Plenty of studies have indicated that controlling irrational use of antibiotics is mainly by the means of regulating the rationality of antibiotics on doctors' prescription and improving populations' correct knowledge, attitudes and behaviors about antibiotics[52-54]. There are already many campaigns successfully held at a national or regional level in many high-income countries to educate the public appropriate use of antibiotics, including Australia, Canada, France, the UK, New Zealand and so on[55]. China has also issued a "Restriction Order" that antibiotics should be purchased by prescriptions, restricting the behavior of antibiotics purchased without prescription in China and inappropriate antibiotic use. The results showed that parents of different nationalities living in China had different performances on knowledge, attitudes and behaviors about antibiotics. The overall accuracy of Occidental parents was higher than that of Chinese, followed by other Asians. Respondents living in Xi'an under the same supplier of health environment and norms yet presented differently on antibiotic use, which probably shows that residents in Occident are better educated on knowledge and attitudes about antibiotics than population in China area. Knowledge and attitudes are more effected by self-awareness and education popularization in the original place of residence. In Occident, educational campaigns of the rational use of antibiotics have been carried out earlier than China and other Asia countries and have already got excellent achievements[55], therefore Occidental parents' knowledge and attitudes about antibiotics are superior to Chinese parents and other Asians too. In the context of a consistent health service supply environment, people's behaviors are mainly determined by knowledge and attitudes[56], so it is reasonable that Occidental parents performs better on using antibiotics than China due to Occidental parents' higher knowledge and attitudes about antibiotics. Health education on antibiotic-related knowledge is particularly important. Publicity and education on such related fields for residents should be paid much attention by Chinese government. Besides, the residents' awareness of accepting education needs to be improved. With time going by, it is likely to constantly drive residents to use antibiotics appropriately and further decrease the speed of bacterial resistance by the means of reducing parental self-medication with antibiotics for their children initiatively.

Item "Repeatedly using an antibiotic is prone to have bacterial resistance" was the best acknowledge of antibiotic knowledge among three nationalities of parents, with $84.30 \%$ of Chinese parents, $76.00 \%$ of other Asians and $90.67 \%$ of Occidental parents, showing that Occidental parents had a better performance than Chinese parents, followed by other Asian parents. The results are higher than some studies in other regions $[21,57]$. It may related to the fact that a series of educational activities on the rational use of antibiotics has been carried out in China since 2010[58], which makes residents living in China have such a better understanding of bacterial resistance. Although the education has achieved certain achievements, bacterial resistance knowledge of Chinese parents is still weaker than Occidental due to the late implementation time in China, let alone other Asia countries.

In item "Agree that antibiotics should be used immediately when your child has Upper Respiratory Tract Infections", we found that $30.58 \%$ Chinese parents, $25.33 \%$ Occidental parents had such thought and Occidental parents performed better but both still not good enough. There are already many studies presented that Upper Respiratory Tract Infections in children are mainly caused by viral infections instead of bacteria $[59,60]$. Antibiotics are targeted at infections caused by bacteria, but has little effect on killing 
virus. Nowadays, parents have such great expectations for the antibiotics that ignoring the fact that ailment of their children may not be microbial in origin, or it may not be bacterial in nature even if its cause is microbial. Parents should be aware of antibiotic indications and educated more on knowledge related to antibiotics, especially for Chinese parents and other Asians.

There are several limitations of this study that need to be further addressed in future studies. The study is retrospective, so recall bias on whether there was parental self-medication with antibiotics for children in the past 6 months in the survey is possible. Besides, the targeted people of this study is limited in an International Department of an International School in Xi'an, Shaanxi Province due to time, manpower and other conditions, resulting the relatively small sample size. However, considering the concentration on parents of different nationalities in school, the results of our findings can basically reflect the fact the difference in self-medication with antibiotics for children, as well as knowledge, attitudes and behaviors about antibiotics of parents of different nationalities.

\section{Conclusions}

The study found that parents' nationality was an influencing factor on parental self-medication with antibiotics for children that Chinese parents were more likely to self-medicate for their children than Occidental parents. What's more, Occidental parents performed better than Chinese and other Asian parents in knowledge, attitudes and behaviors about antibiotics. It is recommended for health administration not only to strengthen the supervision and regulation to health service supplier, but also health education to parents on knowledge, attitudes and behaviors about antibiotics by means of brochures, poster, lectures and pushing related knowledge message through Internet.

\section{Declarations}

\section{Acknowledgments:}

Not applicable.

\section{Authors' contributions:}

ZZ, DZ, HZ and LZ designed and conceptualized the study. DZ interpreted the statistical results and drafted the manuscript. $Z Z$ contributed to the editing and polishing of the manuscript. $\mathrm{HZ}$ was responsible for the quality control of investigation and coordination of study spot. YZ, DC and YR investigated and collected the data. DZ analysed the data and CS provided statistical analysis guidance and results' interpretation. YS and SM offered suggestions on study and critically revised the manuscript. All of the authors have read and approved the final manuscript as submitted.

\section{Funding:}


This study was funded by China Medical Board (15-277 and 16-262), National Natural Science Foundation of China (71874137) and Shaanxi Social Science Foundation (2017S024).

\section{Availability of data and materials:}

The datasets used and/or analyzed during the current study are available from the corresponding author on reasonable request.

\section{Ethics approval and consent to participate:}

Ethical approval for this project was granted by the department of science, technology and discipline construction at Xi'an Jiaotong University (No: 2019-1169). In case participants weren't able to write and consideration of convenience and efficiency, verbal informed consent approved by the ethics committee was obtained from all participants before we investigators told them the survey purpose and privacy safety printed at the top of the questionnaire.

\section{Consent for publication:}

Not applicable.

\section{Competing interests:}

The authors declare that they have no competing interests. We declare that Prof. Zhongliang Zhou is a member of the editorial board (Associate Editor) of this journal.

\section{Author details:}

${ }^{1}$ School of Public Policy and Administration, Xi'an Jiaotong University, No. 28 Xianning West Road, Xi'an, Shaanxi 710049, China. ${ }^{2}$ Xi'an Lianhu District Huoshaobei Clinic, No. 15, 1 st Floor, Building A, Weilanhuacheng Community, Lianhu District, Xi'an, Shaanxi 710077, China. ${ }^{3}$ Department of Health Care Management and Medical Education, The School of Military Preventive Medicine, Air Force Medical University, No.169,Changle West Road, Xi'an, Shaanxi 710032, China. ${ }^{4}$ School of Public Health, Health Science Center, Xi'an Jiaotong University, No.76 Yanta West Road, Xi'an, Shaanxi 710061, China. ${ }^{5}$ Department of Health Policy and Management, Yale University, New Haven, CT 06520, USA. ${ }^{6}$ Research Center of Stomatology, College of Stomatology, Xi'an Jiaotong University, No.98 West 5 Road, Xi'an, Shaanxi 710004, China. ${ }^{7}$ School of Pharmacy, Health Science Center, Xi'an Jiaotong University, No.76 Yanta West Road, Xi'an, Shaanxi 710061, China.

\section{References}

1. Eystathios S, Panagiotis M, Athanasia P, Aristofanis G, George M, Christos P, loannis T, Irene Z, Alexios V, Petroula S. Self-medication with antibiotics in rural population in Greece: a cross-sectional multicenter study. BMC family practice. 2010;11(1):58. 
2. Spencer JR, Milburn EK, Chukwuma U. Correlation between antimicrobial resistance in Escherichia coli infections in hospitalized patients and rates of inpatient prescriptions for selected antimicrobial agents, Department of Defense hospitals, 2010-2014. MSMR. 2016; 23(3):6-10.

3. Eliopoulos GM, Cosgrove SE, Carmeli Y. The Impact of Antimicrobial Resistance on Health and Economic Outcomes. Clinical infectious diseases. 2003; 36(11):1433-1437.

4. Gao J, Rong J, Qiao F, Shan J. Investigation of KAP About the Rational Use of Antibiotics in Community Children's Families囚in Chinese区. Health Education and Health Promotion. 2017; 12(2):146-149.

5. WHO. Antimicrobial resistance: Global report on surveillance. World Health Organization; 2014.

6. Liu Y, Yang Y. The analysis and suggestion about antibiotics abuse in China冈in Chinese邓. China modern doctor. 2016; 54(29):160-164.

7. Goossens H, Ferech M, Vander Stichele R, Elseviers M. Outpatient antibiotic use in Europe and association with resistance: a cross-national database study. The Lancet. 2005; 365(9459):579-587.

8. Holmberg S, Bo R. Dying of corruption. Health Economics Policy Law. 2011; 6(4):529-547.

9. Peter C, Prema-chandra A, Sanjaya S, Fahad K, John C. Antimicrobial Resistance: The Major Contribution of Poor Governance and Corruption to This Growing Problem. PLoS One. 2015; 10(3):e0116746.

10. Sah S, Fugh-Berman A. Physicians under the Influence: Social Psychology and Industry Marketing Strategies. The Journal of Law, Medicine \& Ethics. 2013; 41(3):665-672.

11. Navarro-San Francisco C, Del Toro MD, Cobo J, De Gea-García JH, Vañó-Galván S, Moreno-Ramos F, Rodríguez-Baño J, Paño-Pardo JR. Knowledge and perceptions of junior and senior Spanish resident doctors about antibiotic use and resistance: Results of a multicenter survey. Enfermedades infecciosas y microbiologia clinica. 2013; 31(4):199-204.

12. Kardas $P$, Pechère J-C, Hughes DA, Cornaglia G. A global survey of antibiotic leftovers in the outpatient setting. International journal of antimicrobial agents. 2007; 30(6):530-536.

13. Dimova R, Dimitrova D, Semerdjieva M, Doikov I. Patient Attitudes and Patterns of Self-Medication with Antibiotics - A Cross-Sectional Study in Bulgaria. Macedonian Journal of Medical Sciences. 2015; 7(4):655-661.

14. Bi P, Tong S, Parton KA. Family self-medication and antibiotics abuse for children and juveniles in a Chinese city. Social science \& medicine. 2000; 50(10):1445-1450.

15. Askarian M, Maharlouie N. Irrational Antibiotic Use among Secondary School Teachers and University Faculty Members in Shiraz, Iran. International journal of preventive medicine. 2012; 3(12):839-845.

16. Huang Y, Gu J, Zhang M, Ren Z, Yang W, Chen Y, Fu Y, Chen X, Cals JW, Zhang F. Knowledge, attitude and practice of antibiotics: a questionnaire study among 2500 Chinese students. BMC medical education. 2013; 13(1):163. 
17. Francesco N, Teresa IM, Gabriella DG, F Al, Axel C. Public Knowledge, Attitudes, and Experience Regarding the Use of Antibiotics in Italy. PloS one. 2013; 8(12):e84177.

18. Siddiqui S, Cheema MS, Ayub R, Shah N, Raza SM. Knowledge, attitudes and practices of parents regarding antibiotic use in children. Journal of Ayub Medical College Abbottabad. 2014; 26(2):170173.

19. Sun KS, Seongmi M, Jung KE. Public Knowledge and Attitudes Regarding Antibiotic Use in South Korea. Journal of Korean Academy of Nursing. 2011; 41(6):742-749.

20. Andre M, Vernby A, Berg J, Lundborg CS. A survey of public knowledge and awareness related to antibiotic use and resistance in Sweden. Journal of Antimicrobial chemotherapy. 2010; 65(6):12921296.

21. Lim KK, Teh CC. A Cross Sectional Study of Public Knowledge and Attitude towards Antibiotics in Putrajaya, Malaysia. Southern Med Review. 2012; 5(2):26-33.

22. Chan YH, Fan MM, Fok C-M, Lok ZL, Ni M, Sin C-F, Wong K-K, Wong S-M, Yeung R, Yeung TT. Antibiotics nonadherence and knowledge in a community with the world's leading prevalence of antibiotics resistance: Implications for public health intervention. American journal of infection control. 2012; 40(2):113-117.

23. Morgan DDJ, Okeke IN, Laxminarayan R, Perencevich EN, Weisenberg S. Non-prescription antimicrobial use worldwide: A systematic review. The Lancet infectious diseases. 2011;11(9):692701.

24. Abdelmoneim A, Idris E, Lloyd M, Lukman T. Self-medication with antibiotics and antimalarials in the community of Khartoum State, Sudan. J Pharm Pharm Sci. 2005; 8(2):326-331.

25. Whittaker A. Guidelines for the Identification and Management of Substance Use and Substance Use Disorders in Pregnancy By World Health Organization Geneva, Switzerland. Drug and Alcohol Review. 2015; 34(3):340-341.

26. Quan-Cheng K, Jian-Guo W, Xiang-Hua L, Zhen-Zhen L. Inappropriate use of antibiotics in children in China. The Lancet. 2016; 387(10025):1273-1274.

27. Liao R. Investigation on the Impact of Parents' Cognitive Level of Antibiotics on Selfdirected Use of Antibiotics in Pupils (in Chinese). Practical Preventive Medicine. 2013; 20(1):42-45.

28. Oshikoya KA, Njokanma OF, Bello JA, Ayorinde EO. Family self-medication for children in an urban area of Nigeria. Paediatric and Perinatal Drug Therapy. 2007; 8(3):124-130.

29. Jasim A. PARENTAL SELF MEDICATION OF ANTIBIOTICS FOR CHILDREN IN BAGHDAD CITY, Int J Pharm Pharm Sci. 2014; 6(10):485-489.

30. Eric D, Patience T-Q, Patrick N, Isaac A. Self-Medication Practices with Antibiotics among Tertiary Level Students in Accra, Ghana: A Cross-Sectional Study. Int J Environ Res Public Health. 2012; 9(10):3519-3529.

31. Jie $H$, Wang Z. Knowledge, attitudes and perceptions regarding antibiotic use and self-medication: $A$ cross-sectional study among Australian Chinese migrants. Healthcare Infection. 2015; 20(1):23-28. 
32. Harbarth S, Samore MH. Antimicrobial Resistance Determinants and Future Control. Emerging infectious diseases. 2005; 11(6):794-801.

33. Grigoryan L, Monnet D, Haaijer-Ruskamp F, Bonten M, Lundborg S, Verheij T. Self-Medication with Antibiotics in Europe: A Case for Action. Current Drug Safety. 2010; 5(4):329-332.

34. Barah F, V G. Antibiotic use and knowledge in the community in Kalamoon, Syrian Arab Republic: a cross-sectional study. Eastern MediterraneanHealth Journal. 2010; 16(5):516-522.

35. HUI L, LI X-S, ZENG X-J, DAI Y-H, FOY HM. Patterns and determinants of use of antibiotics for acute respiratory tract infection in children in China. The Pediatric infectious disease journal. 1997; 16(6):560-564.

36. Edwards DJ, Richman PB, Bradley K, Eskin B, Mandell M. Parental use and misuse of antibiotics: Are there differences in urban vs. suburban settings? Academic emergency medicine: official journal of the Society for Academic Emergency Medicine. 2002; 9(1):22-26.

37. Mcnulty CAM, Boyle P, Nichols T, Clappison P, Davey P. The Public's Attitudes to and Compliance with Antibiotics. Journal of Antimicrobial Chemotherapy. 2007; 60 Suppl 1:i63-i68.

38. Mitsi G, Jelastopulu E, Basiaris H, Skoutelis A, Gogos C. Patterns of antibiotic use among adults and parents in the community: A questionnaire-based survey in a Greek urban population. International journal of antimicrobial agents. 2005; 25(5):439-443.

39. Väänänen $M H$, Pietilä K, Airaksinen M. Self-medication with antibiotics-Does it really happen in Europe? Health policy. 2006; 77(2):166-171.

40. Alszzam SI, Alhusein BA, Alzoubi F, Masadeh MM, Alhorani MA. Self-Medication with Antibiotics in Jordanian Population. International journal of occupational medicine and environmental health. 2007; 20(4):373-380.

41. Abasaeed A, Vlcek J, Abuelkhair M, Kubena A. Self-medication with antibiotics by the community of Abu Dhabi Emirate, United Arab Emirates. J Infect Dev Ctries. 2009; 3(7):491-497.

42. Alumran A, Yu Hou X, Sun J, Yousef A, Hurst C. The Parental Use of Antibiotics in Children in Saudi Arabia. Epidemiology: Open Access. 2015; 05(03).

43. Okumura J, Wakai S, Umenai T. Drug utilisation and self-medication in rural communities in Vietnam. Social science \& medicine. 2002; 54(12):1875-1886.

44. Shankar PR, Partha P, Shenoy N. Self-medication and non-doctor prescription practices in Pokhara valley, Western Nepal: A questionnaire-based study. BMC family practice. 2002; 3(1):1-7.

45. Jin J, Jiang T, Zeng Z. Preventing the growth of "superbugs"-Regulating the rational use of antibiotics『in Chinese区. World Notes on Antibiotics. 2011; 32(1):46-48.

46. Al-Dossari K. Parental Knowledge, Attitude and Practice on Antibiotic use for Upper Respiratory Tract Infections in Children. Majmaah J Heal Sci. 2013; 1(1):33-45.

47. Panagakou SG, Spyridis N, Papaevangelou V, Theodoridou KM, Goutziana GP, Theodoridou MN, Syrogiannopoulos GA, Hadjichristodoulou CS. Antibiotic use for upper respiratory tract infections in 
children: A cross-sectional survey of knowledge, attitudes, and practices (KAP) of parents in Greece. BMC pediatrics. 2011; 11(1):60-60.

48. Zyoud SEH, Taha AA, Araj KF, Abahri IA, Sawalha AF, Sweileh WM, Awang R, Aljabi SW. Parental knowledge, attitudes and practices regarding antibiotic use for acute upper respiratory tract infections in children: a cross-sectional study in Palestine. BMC pediatrics. 2015; 15(1):176.

49. Abula T, Worku A. Self-medication in three towns of North West Ethiopia. Ethiopian Journal of Health Development. 2005; 15(1):25-30.

50. Kardas P, Devine S, Golembesky A, Roberts C. A systematic review and meta-analysis of misuse of antibiotic therapies in the community. International journal of antimicrobial agents. 2005; 26(2):106113.

51. Lowman N, Bowden RG. Parental factors associated with injudicious antibiotic-seeking behavior. American journal of health behavior. 2010; 34(5):633-640.

52. Radyowijati A, Haak H. Improving antibiotic use in low-income countries: an overview of evidence on determinants. Social science \& medicine. 2003; 57(4):733-744.

53. Jodi VE, Ruthanne M, L. HJ, Beth I, J. VD, R. CP, Elizabeth Z, Valerie D, Gibbs MK, M. ZS. Consumer Attitudes and Use of Antibiotics. Emerging infectious diseases. 2003; 9(9):1128-1135.

54. Steinke DT, Bain DJG, MacDonald TM, Davey PG. Practice factors that influence antibiotic prescribing in general practice in Tayside. Journal of Antimicrobial Chemotherapy. 2000; 46(3):509512.

55. Huttner B, Goossens H, Verheij T, Harbarth S. Characteristics and outcomes of public campaigns aimed at improving the use of antibiotics in outpatients in high-income countries. The Lancet infectious diseases. 2010; 10(1):17-31.

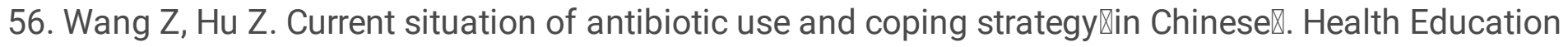
and Health Promotion. 2013; 8(2):125-128.

57. You JHS, Yau B, Choi KC, Chau CTS, Huang QR, Lee SS. Public Knowledge, Attitudes and Behavior on Antibiotic Use: A Telephone Survey in Hong Kong. Infection. 2008; 36(2):153-157.

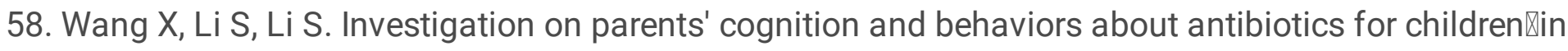
Chinese冈. J Mod Med Health. 2014; 30(11):1749-1750.

59. Nordlie A-L, Andersen BM. Parents' attitudes to the prescription of antibiotics to children. Tidsskr Nor Laegeforen. 2004; 124(17):2229-2231.

60. Buñuel Alvarez JC, Fortea Gimeno E, Cortés Marina RB, Vila Pablos C, Blanch Risec F, Estany Delgado M. Antibiotic use in primary care. Do we know what parents think? Anales de Pediatría. 2004; 61(4):298-304.

\section{Tables}

Table 1 Questionnaire description 


\begin{tabular}{|c|c|c|c|}
\hline Part & Block & e & $\begin{array}{l}\text { Correct } \\
\text { answer }\end{array}$ \\
\hline \multirow[t]{2}{*}{ First } & $\begin{array}{l}\text { Socio-demographic } \\
\text { characteristics of } \\
\text { the respondents }\end{array}$ & $\begin{array}{l}\text { Age, Gender, Nationality, Education level, } \\
\text { Occupation, Having health workers at home or }\end{array}$ & l \\
\hline & $\begin{array}{l}\text { Parental self- } \\
\text { medication with }\end{array}$ & $\begin{array}{l}\text { Did you self-medicate with antibiotics for } \\
\text { children in the past } 6 \text { months }\end{array}$ & I \\
\hline \multirow[t]{17}{*}{ Second } & Antibiotic & 1. Antibiotics are anti-inflammatory drugs & Wrong \\
\hline & & 2. Antibiotics can kill or inhibit the virus & Wrong \\
\hline & & 3. Antibiotics are purchased by a prescription & Right \\
\hline & & 4. Most of the Upper Respiratory Tract & Right \\
\hline & & 5. Repeatedly using an antibiotic is prone to & Right \\
\hline & & $\begin{array}{l}\text { 6. Deficiency use of antibiotics leads to bacterial } \\
\text { resistance }\end{array}$ & Right \\
\hline & Antibiotic attitudes & $\begin{array}{l}\text { 1. Agree that antibiotics should be used } \\
\text { immediately when your child has Upper }\end{array}$ & No \\
\hline & & $\begin{array}{l}\text { Respiratory Iract Infections } \\
\text { 2. Agree that expensive antibiotics work better }\end{array}$ & No \\
\hline & & 3. Agree that broad-spectrum antibiotics are & No \\
\hline & & 4. Agree that intravenous antibiotics (infusion) & No \\
\hline & & $\begin{array}{l}\text { 5. Agree that parents can self-medicate with } \\
\text { antibiotics for their children based on children's } \\
\text { condition when disease is mild }\end{array}$ & No \\
\hline & Antibiotic behaviors & $\begin{array}{l}\text { 1. Antibiotic is available at home to medicate } \\
\text { children timely when they are sick }\end{array}$ & No \\
\hline & & 2. Will give children multiple antibiotics at the & No \\
\hline & & $\begin{array}{l}\text { 3. Will use leftover antibiotics if children have } \\
\text { similar symptoms }\end{array}$ & No \\
\hline & & 4. Will ask for a doctor to prescribe antibiotics & No \\
\hline & & 5. Will change the dosage of antibiotics & No \\
\hline & & $\begin{array}{l}\text { according to the course of alsease of children } \\
6 \text {. Will change the type of antibiotics when you } \\
\text { use antibiotics }\end{array}$ & No \\
\hline
\end{tabular}

Table 2 Sample description 


\begin{tabular}{|c|c|c|c|c|c|c|}
\hline \multirow[t]{2}{*}{ Variable } & \multicolumn{2}{|c|}{$\begin{array}{l}\text { Chinese } \\
(\mathrm{N}=121)\end{array}$} & \multicolumn{2}{|c|}{$\begin{array}{l}\text { Other Asians } \\
\qquad(\mathrm{N}=100)\end{array}$} & \multicolumn{2}{|c|}{$\begin{array}{c}\text { Occidental } \\
(\mathrm{N}=75) \\
\end{array}$} \\
\hline & $\mathrm{n}$ & $\%$ & $\mathrm{n}$ & $\%$ & $\mathrm{n}$ & $\%$ \\
\hline \multicolumn{7}{|l|}{ Gender } \\
\hline Male & 19 & 15.70 & 27 & 27.00 & 47 & 62.67 \\
\hline Female & 102 & 84.30 & 73 & 73.00 & 28 & 37.33 \\
\hline $\begin{array}{l}\text { Age } \\
\text { Mean (sd) }\end{array}$ & \multicolumn{2}{|c|}{$37.96(5.447)$} & \multicolumn{2}{|c|}{$40.76(3.610)$} & \multirow{3}{*}{\multicolumn{2}{|c|}{$\begin{array}{cc}39.44 & (4.630) \\
18 & 24.00 \\
27 & 36.00 \\
30 & 40.00\end{array}$}} \\
\hline $\begin{array}{l}25-34 \\
35-39 \\
40-55\end{array}$ & $\begin{array}{l}48 \\
34 \\
39\end{array}$ & $\begin{array}{l}39.67 \\
28.10 \\
32\end{array}$ & $\begin{array}{c}6 \\
45 \\
49\end{array}$ & $\begin{array}{c}6.00 \\
45.00\end{array}$ & & \\
\hline Education level & & $32 . \angle 0$ & & & & \\
\hline Postgraduate and above & 44 & 36.36 & 19 & 19.00 & 45 & 60.00 \\
\hline Undergraduate & 55 & 45.45 & 53 & 53.00 & 26 & 34.67 \\
\hline $\begin{array}{l}\text { Junior college and below } \\
\text { Occupation }\end{array}$ & & 18.19 & & 28.00 & & \\
\hline Staff & 12 & 9.92 & 18 & 18.00 & 4 & 5.33 \\
\hline Official cadre & 3 & 2.48 & 9 & 9.00 & 8 & 10.67 \\
\hline Doctor & 3 & 2.48 & 4 & 4.00 & 4 & 5.33 \\
\hline Teacher & 25 & 20.66 & 6 & 6.00 & 30 & 40.00 \\
\hline Business manger & 35 & 28.93 & 23 & 23.00 & 25 & 33.33 \\
\hline Self-employed & 18 & 14.88 & 1 & 1.00 & 0 & 0.00 \\
\hline Others & 25 & 20.65 & 39 & 39.00 & 4 & 5.34 \\
\hline $\begin{array}{l}\text { Having health workers at home or not } \\
\text { Yes }\end{array}$ & 25 & 2067 & 14 & 14.00 & 20 & 2667 \\
\hline No & 96 & 79.33 & 86 & 86.00 & 55 & 73.33 \\
\hline Income & & & & & & \\
\hline Up to 0.5 million & $\begin{array}{l}62 \\
30\end{array}$ & $\begin{array}{l}51.24 \\
24.79\end{array}$ & 37 & $\begin{array}{l}37.00 \\
46.00\end{array}$ & 67 & 89.33 \\
\hline Above 10 million & 29 & 23.97 & 17 & $\begin{array}{l}40.00 \\
17.00\end{array}$ & 3 & 4.00 \\
\hline
\end{tabular}

Table 3 Influencing factors of parental self-medication with antibiotics 


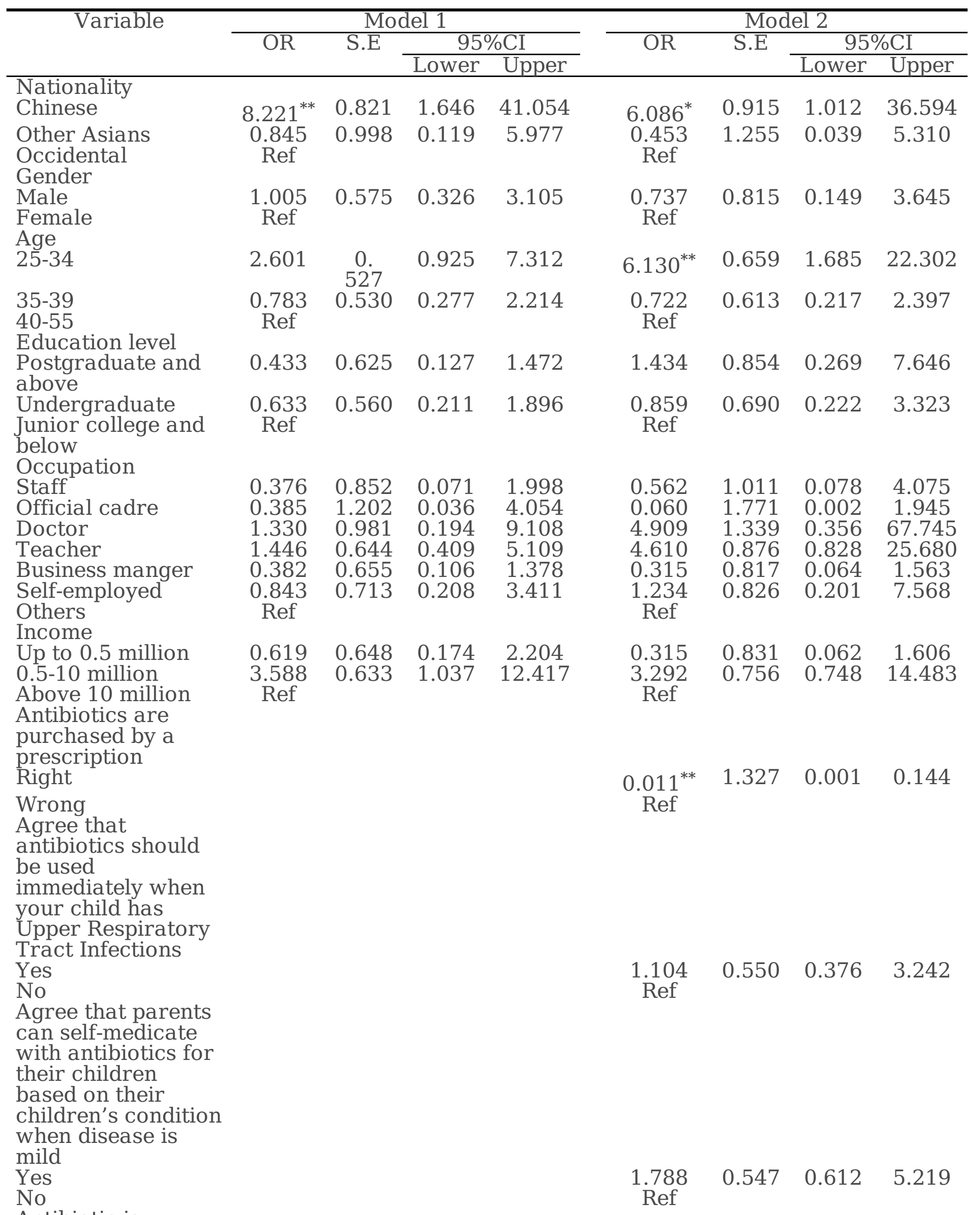

Antibiotic is

available at home 
to medicate

children timely

when they are sick

Yes

0.671

0.854

0.126

3.581

No Ref

Will use leftover

antibiotics if your

children have

similar symptoms

Yes

3.202

Ref

0.618

$0.953 \quad 10.754$

No

Will ask for a

doctor to prescribe

antibiotics if the

doctor does not

prescribe an

antibiotic

Yes

No

$15.288^{* *}$

$0.876 \quad 2.746$

85.111

Ref

${ }^{*} P \leq 0.05,{ }^{* *} P \leq 0.01$

Table 4 Correct knowledge about antibiotics of parents of different nationalities

\begin{tabular}{|c|c|c|c|c|c|c|c|c|}
\hline \multirow[t]{2}{*}{ Item } & \multicolumn{2}{|c|}{ Chinese $₫ N=121 \square$} & \multicolumn{2}{|c|}{$\begin{array}{c}\text { Other Asians } \\
\square N=100 \square\end{array}$} & \multicolumn{2}{|c|}{ OccidentalnN=75 } & \multirow[t]{2}{*}{$\mathrm{c}^{2}$} & \multirow[t]{2}{*}{$\begin{array}{c}P \\
\text { value }\end{array}$} \\
\hline & $\mathrm{n}$ & $\%$ & $\mathrm{n}$ & $\%$ & $\mathrm{n}$ & $\%$ & & \\
\hline $\begin{array}{l}\text { Antibiotics aren't } \\
\text { anti-inflammatory }\end{array}$ & 55 & 45.45 & 26 & 26.00 & 45 & 60.00 & 20.963 & $<0.001$ \\
\hline $\begin{array}{l}\text { drugs } \\
\text { Antibiotics can't kill }\end{array}$ & 58 & 47.93 & 15 & 15.00 & 39 & 52.00 & 33.814 & $<0.001$ \\
\hline $\begin{array}{l}\text { Antibiotics are } \\
\text { purchased by a }\end{array}$ & 97 & 80.17 & 64 & 64.00 & 67 & 89.33 & 16.683 & $<0.001$ \\
\hline $\begin{array}{l}\text { prescription } \\
\text { Most of the Upper } \\
\text { Respiratory Tract } \\
\text { Infections are viral } \\
\text { infection }\end{array}$ & 67 & 55.37 & 49 & 49.00 & 38 & 50.67 & 0.965 & 0.617 \\
\hline $\begin{array}{l}\text { Repeatedly using an } \\
\text { antibiotic is prone } \\
\text { to have bacterial } \\
\text { resistance }\end{array}$ & 102 & 84.30 & 76 & 76.00 & 68 & 90.67 & 6.773 & 0.034 \\
\hline $\begin{array}{l}\text { Deficiency use of } \\
\text { antibiotics leads to }\end{array}$ & 64 & 52.89 & 70 & 70.00 & 48 & 64.00 & 7.035 & 0.030 \\
\hline $\begin{array}{l}\text { bacterial resistance } \\
\text { Total }\end{array}$ & 443 & 61.02 & 300 & 50.00 & 305 & 67.78 & 36.650 & $<0.001$ \\
\hline
\end{tabular}

Table 5 Correct attitudes about antibiotics of parents of different nationalities 


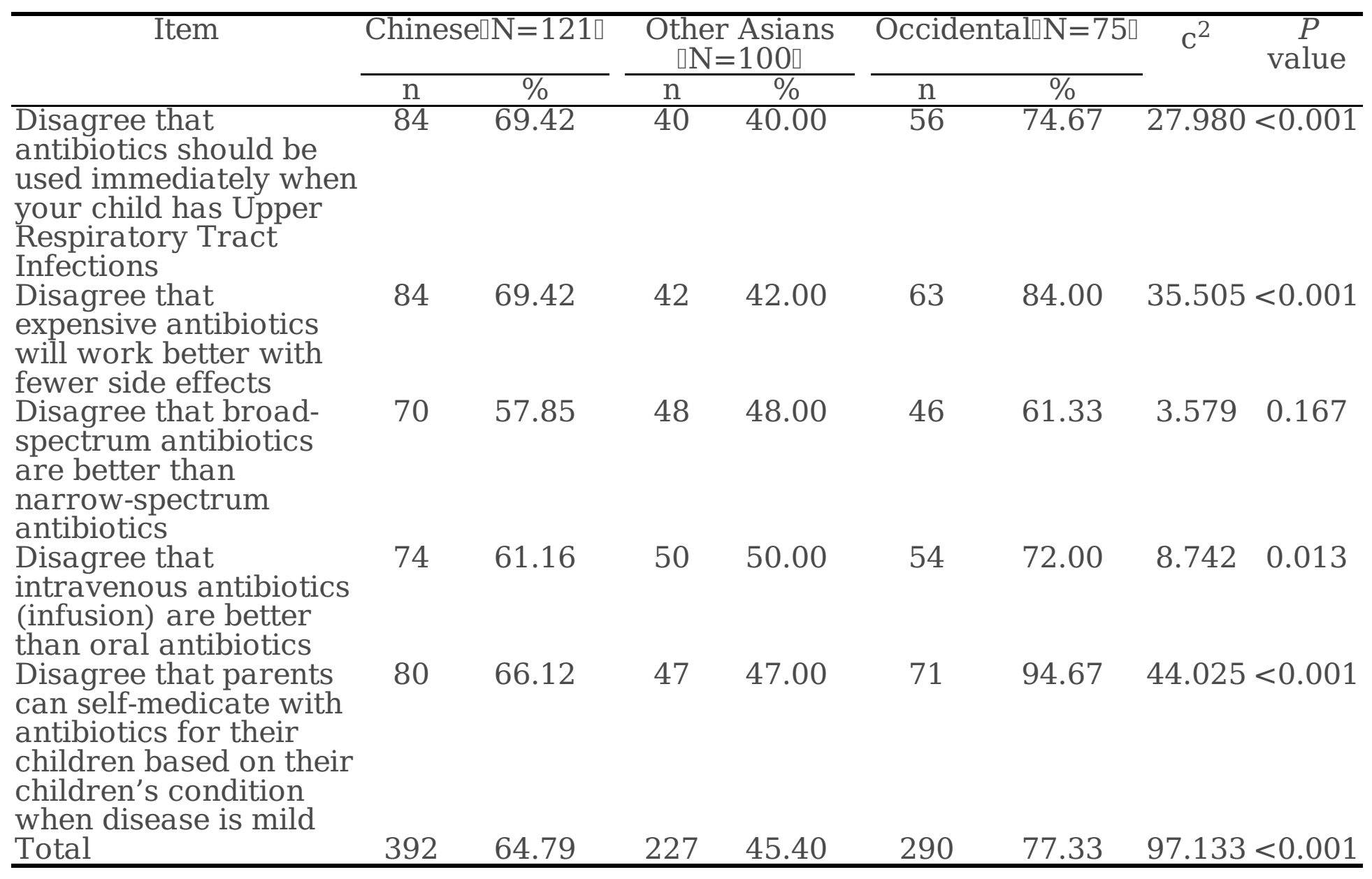

Table 6 Behaviors about antibiotics of parents of different nationalities 


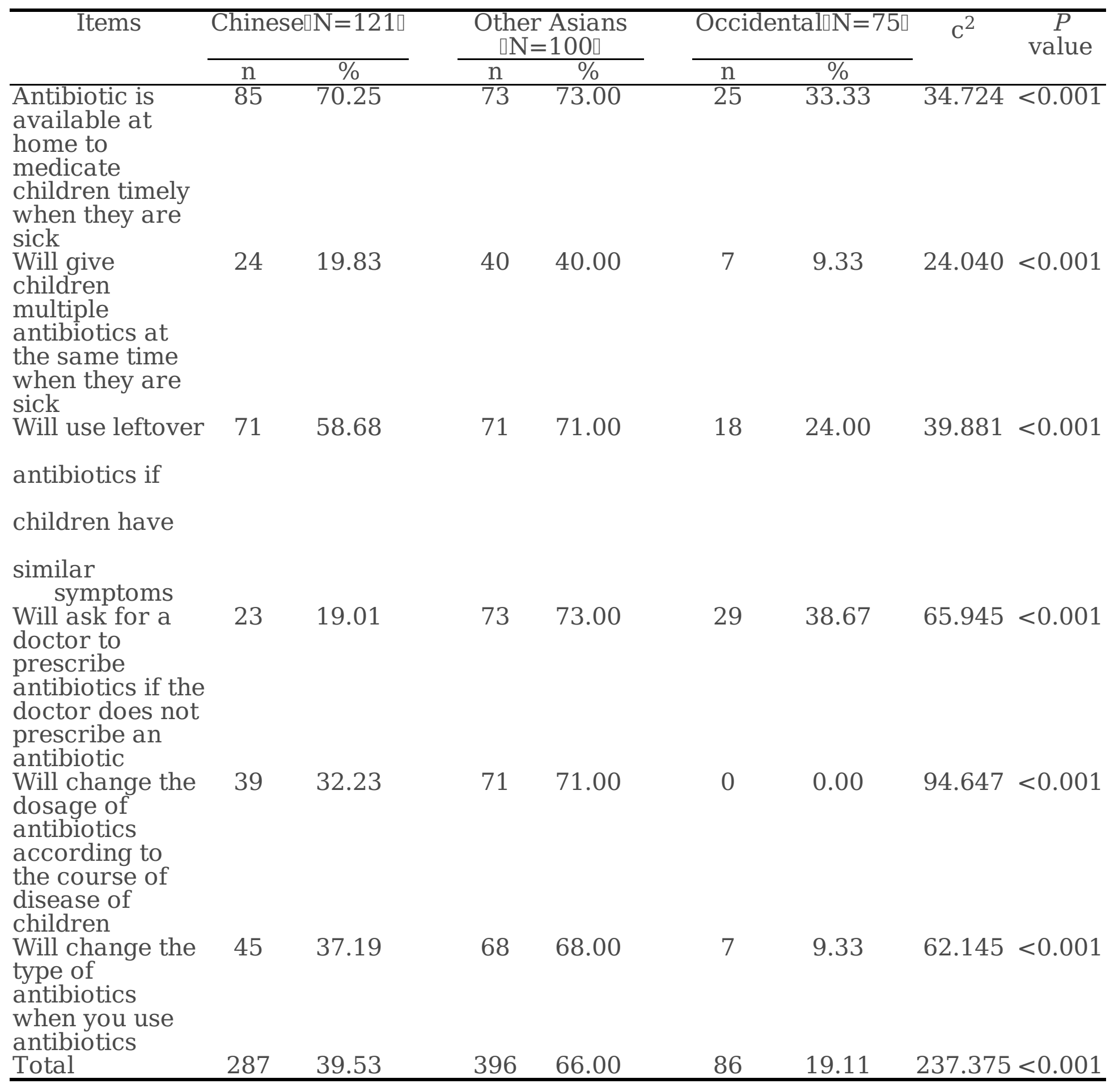

